\title{
An Evaluation of using Group Work to Improve Speaking Fluency for First Year Non-Majored English Students at Dong Nai Technology University
}

\author{
Lam Thi Phan \\ Dong Nai Technology University \\ Bien Hoa city, Dong Nai province, Vietnam
}

\begin{abstract}
The paper is a study of applying group work conducted with non-majored English students in higher education. Both of quantitative and qualitative methods were employed in the study. The results indicate that group work brought a lot of benefits in improving students' speaking fluency. The students have more opportunities for language practice. It also creates a positive atmosphere in classroom for students to interact freely in English that increases their communicative skills. In generally, the students showed favorable attitudes to using of group work activities. Therefore, the researcher suggests that EFL teachers consider applying group work activities in classrooms.
\end{abstract}

Key words: group work; speaking opportunities; fluency.

\section{Introduction}

The growth of English as a global language has increased the emphasis on communicative requirements in English language teaching and learning in Vietnam. Therefore, students' ability to use the target language for communicative purposes is considered as one of the core aims in foreign language learning and teaching. Chaiyasuk, Praphan and Setjun (2013) argue that speaking is an important skill, thereby students can show their language ability; effective language use demonstrates language acquisition of students. In other words, the teaching and learning of a foreign language should not only focus on grammar, but also develop the communicative ability through speaking meaningfully and fluently. In Vietnamese education, English is an obligatory and key subject from primary school to university. It is considered as a necessity in Vietnam society - a developing country has open-door policies to attract foreign investments and trend to global integration. Thus, English is essential to access to more job opportunities, further study as well as for daily communication. 
In spite of the need for communicative skills, many Vietnamese teachers continue to apply Grammar- Translation approach in their EFL classrooms (Son, 2001). As a result, the teacher-centered method produces learners who may get good grades in written examinations, but fail to successfully communicate in real-life situations. This reflects the current reality in Vietnam in general and in the classrooms at Dong Nai Technology University in particular. Most students are not good at speaking. They feel a lack of confidence in communicative skills and are afraid of speaking which makes it difficult for them to communicate successfully in real-life situations.

Based on the identified problem in the teaching context, teachers should use classroom activities which provide students more chances to interact and freely use the target language in classroom; thereby students can enhance their speaking fluency. Moreover, teachers should create exciting activities in classroom that attracts students' attentions. Such activities could help students study foreign language more successfully (Thanomwattana, 2008). According to Burdett and Hastie (2009), group work is a classroom activity in Communicative Language Teaching that creates a setting for peer-to-peer studying; group work involves students with each other in meaningful interaction for improving oral skills. From the reasons mentioned above, the topic of using group work effectively for first year non-majored English students at Dong Nai Technology University is clarified so that group work activities will be used in order to improve students' speaking fluency. The research aims to evaluate the impact of using group work on students' speaking ability and identify students' attitudes to the application of group work in classroom. The research results reveal that group work in EFL classroom brought many advantages in enhancing students' speaking fluency; it increased students' confidence in communicative skills. The students generally showed positive attitudes towards working in groups in the classroom. However, the findings also indicate some students' difficulties in participating in group work.

The evaluation research report includes the following main sections:

- Introduction - show the importance of the topic, the problems and the aims of the research.

- Rationale and theoretical perspectives - review the literature relevant to the research topic.

- Description of the classroom research - give a clear description of the innovation study.

- Evaluation methods - present in detail data collection procedures of questionnaire, interview and class observation; data analysis process; and ethical issues.

- Results - demonstrate the results collected from questionnaire, interview and class observation.

- Discussion - make combination of the findings to evaluate the innovation and then give some suggestions and the limitation of the research.

- Conclusion - summarize the main insights of the evaluation. 


\section{Rationale and theoretical perspectives}

In order to achieve the objective of speaking ability, there are various factors involved, and classroom activities is one of the most important elements which help students improve their proficiency. The use of group work activity has been supported by pedagogical research which suggests that it brings many benefits in EFL classroom. Different studies also indicate that group work develops students' communicative competence (Jiang, 2009; Xue, 2013). Therefore, it is necessary to clarify whether the application of group work brings practical benefits to DNTU students. The innovation study also helps the researcher improve the teaching performance. To build an evidence base for the research, theoretical background and some previous relevant studies should be reviewed in this section.

\subsection{Group work}

As defined by Adam and Hamm (1990), group work is a form of collaborative learning in which several learners work together to accomplish an assigned task or achieve a certain learning objective. Another author defines group work as an effective method to motivate learners, develop communication and encourage active learning in EFL class (Ibnian, 2012). It has been applied in language learning and teaching in many parts of the world since Communicative Language Teaching (CLT) was emergent. This method appeared because of increasing the need of language use for communicative purposes. According to Brumfit (1984), group work is often considered as an essential feature of CLT method.

An important part of group work is the dynamics of group size. Beebe and Masterson (2003) propose that a small group often includes three or more students. Harmer (2003) also suggests that three or four people are more suitable. Large groups reduce members' opportunity of participation and make some members not contribute actively to the group. However, Davis (1993) maintains that groups of four or five students can work best. In addition, assigning a group is essential to the success of the group. Some teachers allow students to choose their group members, but self-selected groups often fall to friends (Cheng, 2004). This may lead to spending more time socializing than working on group project. A study of Brent and Felder (2001) indicates that groups assigned by teacher are likely to better perform than self-selected groups. There are many group work activities including: games, role-play, drama, interview, information gap, problem solving, jigsaw, picture sequence, however to implement effectively group work in EFL class, teachers should select appropriate techniques to plan it (Brown, 2001). Also, Chuku et al. (2007) and Salas (2005) highly recommend that teachers should provide students with a clear explanation and instruction of activity.

\subsection{Benefits and drawbacks of group work}

Brown (2001) points out that group work offers more opportunities for learners to interact and more freely use the target language. Unlike in traditional language classroom with teacher's dominant talk and leading whole-class 
discussions, in classroom used group work can afford learners longer participation in small groups to practice new structures and exchange opinions. Furthermore, Harmer (2003) also contends that group work activities give learners chances of self-initiated language, role adoption and practicing negotiation of meaning. Therefore, group work increases not only the quantity of talk learners can engage in, but also its quality which make up their communicative competence in the target language.

Other benefit that group work offers is a meaningful context for peer-to-peer studying as Burdett and Hastie (2009) reported in their study at a university. With face-to-face communication in group work, learners are studying to collaborate with each other. They are in a process of discussing, questioning, and organizing to together accomplish learning tasks efficiently (Fang, 2005). Also, learners may receive encouragement and support from peers, for example spontaneous feedback on errors. Teachers serve only as facilitators and monitors while groups engage in their activities. Salas (2005) claims that group work promotes collaborative learning and learners' oral skills, encourages learners to create ideas. As they are learning to justify and clarify their viewpoints when solving a problem or exploring an issue, they are improving their linguistic competence and speaking ability as well.

According to Chen (2004), one of the reasons for low achievement of many foreign language learners is that they do not have enough time to practice the new language. In EFL environment, students hardly have input of the target language in their daily lives. The common input and stimulation of the target language mostly come from the classroom, usually from the teachers. Group work can help a great deal here. It can expose learners to a variety of language items and language functions (William, 2011). Via group work activities such as information gap, role-play, problem-solving, drama and interview, learners get exposure to real-life target language context that permits them to utilize English for communication and expression. This view is supported by McDonough (2004) who notes that in activities of group work, learners can play roles, undertake positions and generate a variety of language functions relevant to those positions and roles which help students much improve their oral skills.

Group work has been proven by practitioners and researchers alike to be an effective way of enhancing performance, promoting learning motivation and reducing students' language learning anxiety, especially with large-size and mixed- level classes (Huie \& Yahya, 2002; Dumus, 2002; Satahl, 1994;). Application of group work in large-size class, many students are highly motivated, expose to real language use, more participate in discussion or speaking activities in groups, and become more successful in terms of communication (Meng, 2009). Obviously, students work in the whole-class context may suffer negative psychological elements that hinder their language learning and acquisition. They are afraid of losing face, being wrong or making errors in public. A study with sixty non-majored English students conducted by Jiang (2009) reveals that small group work creates a non-threatening and relaxed atmosphere for optional studying in the class. Students feel less pressured when they think and speak their opinions without being watched by the whole class or 
teacher. In this way, students can maximize the amount of time available for hearing, using the target language, multi-interaction in this supportive learning environment.

Beside the advantages, some studies also point out drawbacks of group work. Firstly, it relates to chaos and noise, because students discuss at the same time trying to finish their task, so this causes class noise (Salas, 2005). Nevertheless, Doff (1991, p.141) argues that "noise created by group work is often 'good' noise", because students are using English and involving in learning task. Difficulty in controlling the class is also a problem for some teachers (Brow 2001). In some cases, they cannot monitor what students are really doing in groups, their use of native language and their mistakes. However, it could be argued that the use of mother tongue could become an instrument to understand and use the target language accurately; and well-managed group work can encourage peer feedback on errors (Aldosary \& Storch, 2010). Another disadvantage is an individual may dominate in group discussion (Bruke, 2011). This leads to members' dissatisfaction with the group or shy and passive students still tend to remain silent.

\subsection{Attitudes towards group work}

Many researchers have addressed students' attitudes to group work and the findings vary. Through interviews with fourteen Chinese students, Xue (2013) found that students' attitudes to group work went through initial dislike to later acceptance. Also through interviews, the participants in the study of Campbell and $\mathrm{Li}$ (2008) in New Zealand show their positive attitudes to group discussion where they could promote their understanding of culture and enhance their English language skills, but they have negative opinions about group assignments. Wong (2004) further notes that students prefer working individually so that they can control their own time as well as the final product. Conversely, a quantitative research by Tiong and Yong (2004) reports that students prefer learning collaboratively and doing group work in an informal learning setting. The research attempts to address the following questions:

- What are the benefits of using group work to enhance students' speaking fluency?

- What are the students' attitudes towards group work in the classroom?

\section{Description of the classroom research}

The classroom research is conducted at Dong Nai Technology University which is located in Bien Hoa city. Classroom facilities are quite good such as microphone, projector and flexible seatings. The study subjects are the first year students. All students in the university have to take two compulsory courses of foundation English on the first year. Every course lasts more than two months with forty-five periods. Every week, students have English class once with five periods. The assessment is implemented through two exams that mainly focus on grammar, vocabulary and reading. The students in the university come from both urban and rural area. So students' English proficiency levels vary in the same class. It seems that they are familiar with learning and teaching setting 
where teachers dominate the whole class, students become quite passive learners and do not have many chances for oral practice and communication. The overall goal of the small-scale research is to evaluate the effectiveness of applying group work in EFL classroom. Specifically, it aims to clarify whether group work activities bring benefits to enhancing students' speaking fluency and to examine students' reactions to applying group work in the classroom. The duration of the classroom research was eleven weeks. On the first and second week, the researcher made the research plan and gained consent from the dean and the students. Then, the innovation was implemented during seven weeks with seven lessons employing different group work activities such as game, role-play, information gap, interview, and jigsaw. Each lesson takes three periods. These group work activities and lessons were based on the course book - American Headway 2A (2009) and other relevant materials collected from other books and the internet. The innovation was introduced in the classroom in two weeks so that students could be familiar with the new way of teaching. From week 5 to week 9 , the data was collected. Then, the obtained data was analyzed in the last two weeks. The positive findings of the research are beneficial to students' learning outcomes in improving their speaking ability as well as the teaching practice. Many useful things have been found in the research process which support the positive changes in teaching and professional development. Therefore, it is necessary to apply group work for first-year students' next courses in Dong Nai Technology University.

\section{Evaluation methods}

\subsection{Methodology}

A mixture of methods was used in the research. As noted by Kelle (2006), quantitative method is designed to produce reliable data numerically and it is useful for carrying out on a large amount of participants that provides information in breadth. Thus, this method could collect a large number of valuable information from the students in short time. On the contrary, qualitative method aims to gather information in detail and depth. Through this method, the researcher could explore the existing facts in the classroom; directly watch students' performances; and capture their attitudes to the innovation. As Robinson and Savenye (2005) points out that qualitative method is done in natural setting that give researcher insights into participants' activities and viewpoints. In short, the combination of two methods can be used to complement each other to make the findings more valid and reliable; consequently it leads to a stronger evidence for making conclusion.

\subsection{Participants}

Thirty students in class 17DKT2 (six males and twenty-four females) participated in this research. At the time of the research, they were taking a course of foundation English. This was a pre-intermediate level class. They were freshmen who were from department of financial accounting. Their ages ranged from 18 to 20. It should be noted that these participants had different levels of English proficiency. 


\subsection{Data collection}

In the research, questionnaire, class observation and semi-structured interview were exploited as evaluation tools to collect the data for addressing two research questions.

Class observation is considered as one of the main tools utilized by lots of researchers in qualitative research. Data is collected via observing events, people's interactions and behavior in the natural setting (Robinson \& Savenye, 2005). The main strength of class observation is observer can focus on any aspects of the lesson and can provide an objective eye; and see directly what students do rather than what they say they did in the classroom (Richards 2001). Nonetheless, the observer's presence could affect students' behavior. As mentioned, the innovation was conducted in the classroom within seven weeks from week 3 to week 9 . Accordingly, class observation was implemented on week 5, week 7 and week 9 . Each observed lesson lasted two periods. To observe the class more carefully, and the collected data was more objective and not affected by the subjective bias, two colleague were invited to observe the class. She noted down on the available observation form (appendix 2). The class was observed on alternate weeks to see what degree of change and improvement when the innovation was conducted through lessons..

Questionnaire, as Dornyei (2003) states, is one of the most popular tools to collect information from large numbers of respondents. The collected data is more objective since the respondents feel more freely to give answers and are not affected by researcher's opinions. Thus, the questionnaire could avoid interview bias that could affect the reliability of the gathered data. Moreover, this tool allowed the researcher to gather valuable information from all the research subjects. However, to use questionnaire as an effective method, questions need be carefully designed with common words that help respondents easily understand (Hinchey, 2008). The questionnaire consisted of eight closed-ended questions with four-point Likert scale (appendix 3 ). They was delivered to all the students in the classroom on the week 9 after the class observations with the purposes of capturing students' opinions, attitudes to group work activities; and exploring their benefits from students' perceptions and experiences. The students completed the questionnaires within fifteen minutes and they were all collected before the class finished, making up 100\% response rate.

Semi-structured interview, according to Hinchey (2008), enables researcher to further explore participants' views or preference; interviewer can ask more questions and interviewee have more chances and time to express more their views on the related issues. Also, complex questions or dubious words will be cleared up. Hence, this method helped the researcher probe intensively the students' preference, opinions and benefits of group work activities used in the classroom that provided amount of in-depth information. This data also validated the data obtained from the questionnaire. As Dahlberge and McCaig (2010, p. 119) notes: "Being an effective semi-structured interviewer takes a degree of skill and expertise in knowing when to probe further information". Therefore, a trial interview was implemented in advance to give emerging questions based on the students' answers, behaviors and facial expressions, and 
the students could have chance to provide more useful information and immerse themselves in a normal conversation.

Semi-structured interviews were conducted on the final week of the experiment (week 9) to collect informative and richer responses from the students after they took seven lessons with group work activities. The interview questions consisted of five open-ended ones (appendix 4). The researcher randomly selected five out of thirty participants and had face-to-face interviews with them individually in the group-learning room at the university library. The interviews all were conducted in Vietnamese so that the students could express themselves clearly and deeply. Each interview lasted approximately twenty minutes. It is difficult to take notes all said in interview, so these interviews were tape-recorded based on interviewees' consent and later transcribed verbatim and translated.

\subsection{Data analysis}

The next necessary process is to analyze and synthesize the obtained data from observation, questionnaire and interview to make a cohesive and systematic interpretation to answer the research questions.

For the questionnaire data, Microsoft Excel was used to process the collected information. Firstly, the responses on the questionnaire were coded by assigning a numerical value to each (strongly agree $=1$, agree $=2$, disagree $=3$, strongly disagree $=4$ ). Then, all the data was entered accurately into the excel spreadsheet by typing the code of the selected response for each question in the cell under that question's header. This computer software was used to calculate frequencies and percentages of response items for each question. Based on the numerical data in percentages, the students' attitudes and opinions about applying group work in the classroom were identified. The data then was displayed visually in graph, pie chart and table.

For qualitative data, foremost the observational notes and the interview transcripts were reviewed many times and the initial ideas were noted down as well. Two observation notes of two lessons were compared to find out the differences and improvements in students' performance, their engagement as well as classroom atmosphere. The initial code of the interview data was produced to identify the interesting features of the data set in a systematic mode. After sorting the different codes, two major themes were derived that related to the two research questions including: The benefits of group work and student's attitudes towards group work. These themes also reflected what I reviewed from the previous studies. Besides, there was another theme emerged within the analysis process, namely students' obstacles to working in group. The final analysis was done with some selected extracts from the participants for illustration.

\subsection{Ethical consideration}

According to Koshy (2005), ethical issues are particularly important for action researchers due to the small-scale nature of the projects set within the researchers' working context. In the research, the researcher considered the 
ethical issues such as informed consent, confidentiality, anonymity, beneficence, and autonomy to protect the participants from unexpected effects.

Before doing the research, it is necessary to ask for permission from the dean. Then, all the students were known about the research such as the research aim, the selection of participants and the procedures, benefits and possible risks of the research, and the responsibilities and rights of participants. The consent forms were also delivered to thirty students. They freely decided their participation in the research and they could withdraw the research at any time without penalty. Research outcomes would benefit all in improving their learning and the teaching. After that, the consent forms were signed by both of the students and the researcher.

In the research, students were asked to share their experiences and opinions about applying group work in the classroom through interview and questionnaire. Students might be afraid of giving negative comments. Thus, students were not asked for writing their names or other personal information on the questionnaire so that they felt more comfortable to answer honestly all the questions. For interview, students might deal with tension and embarrassment when answering the questions. Therefore, the friendly and open conversations were created to enable them to feel more relaxed for expressing their thoughts and opinions. Their true feedback and answers would be highly appreciated, as every reaction would be factored into the improvement of learning and teaching method. All the answers of participants were respected; their identity information and the collected data were kept confidential.

\section{Results}

\subsection{The results from questionnaire}

The students were asked to rate whether they found group work was an easy way to communicate with each other in English (Q1). The majority of the students showed their agreement, specifically $67 \%$ of students' responses were in agreement and $23 \%$ of them were in strong agreement. It can be seen clearly in the pie chart below that only $10 \%$ of the responses indicated disagreement and there was no response of strong disagreement. These figures show that group work enabled the students to ask information and exchange ideas with each other easily in the classroom and this is no doubt, will affect their speaking fluency.

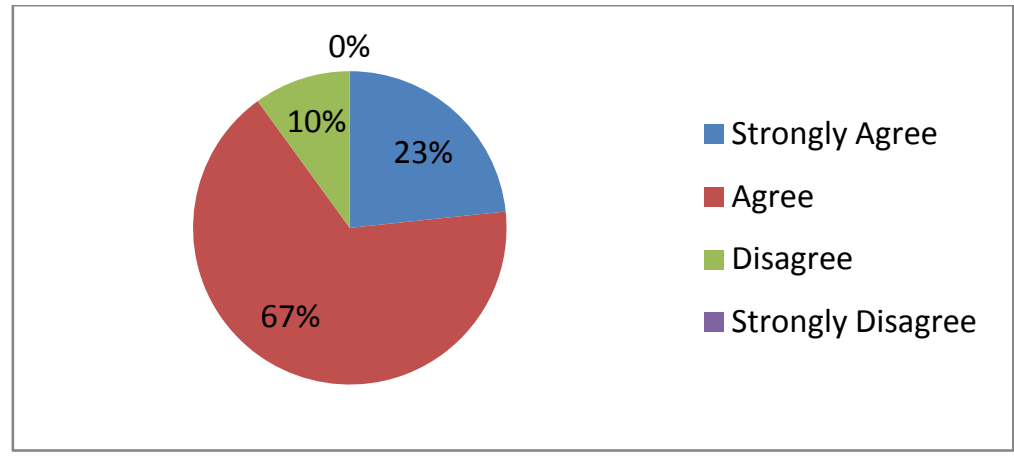

Pie chart 1: Students' opinions about group work as an easy method for communication 
From the below bar graph, it reveals the high percentage of the students agreed $(52 \%)$ and strongly agreed $(39 \%)$ with question 2 "group work provided more chances for speaking practice". This is understandable because in the above pie chart, most students agreed that group work as an easy method to communicate with their peers. Therefore, it seems that students had more time as well as more chances to practice the new language when working in group. Anyway, there are still a few students showed their disagreement. However, the rate of disagreement just occupied $9 \%$ and none of them showed strong disagreement.

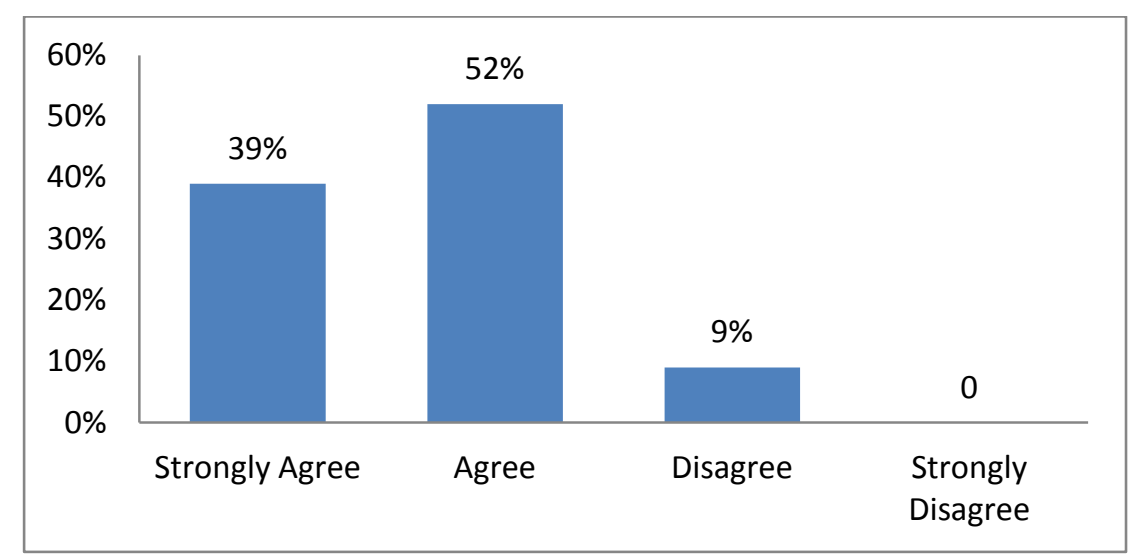

Bar graph 1: Students' opinions about group work provided more chances for speaking practice

The students were also asked to rate their opinions about other aspects of using group work. Table 1 illustrates the results of the students' responses.

Table 1: Students' views on using group work

\begin{tabular}{|l|c|c|c|c|}
\hline Working in group ... & $\begin{array}{c}\text { Strongly } \\
\text { Agree }\end{array}$ & Agree & Disagree & $\begin{array}{c}\text { Strongly } \\
\text { Agree }\end{array}$ \\
\hline $\begin{array}{l}\text { received more useful/helpful } \\
\text { feedback }\end{array}$ & $27 \%$ & $63 \%$ & $7 \%$ & $3 \%$ \\
\hline made you more confident & $67 \%$ & $33 \%$ & $0 \%$ & $0 \%$ \\
\hline helped you do tasks faster and better & $50 \%$ & $37 \%$ & $10 \%$ & $3 \%$ \\
\hline was a waste of time & $0 \%$ & $10 \%$ & $40 \%$ & $50 \%$ \\
\hline $\begin{array}{l}\text { worked best when group size was } \\
\text { four }\end{array}$ & $57 \%$ & $30 \%$ & $10 \%$ & $3 \%$ \\
\hline
\end{tabular}

Table 1 shows the students' views on applying group work in the classroom. To analyze easier, the answers were merged in two categories: 'strongly agree' and 'agree' for 'agree' answer, and 'strongly disagree' and 'disagree' for 'disagree' answer. From table 2 below we can see that most of the items showed 'agree' with the high percentage. $90 \%$ of the students agreed that they received more useful and helpful feedback from their peers in group. Only 3\% of them disagreed. Especially, $100 \%$ of students admitted that working in group made them more confident about themselves. As a result, most students (87\%) indicated group work helped them do tasks faster and better, however the remainder $(13 \%)$ opted for disagreement response. When the plurality of 
students found the benefits of using group work, it was not surprising that $90 \%$ of them disagreed that group work was a waste of time. Noticeably, the results display $87 \%$ of students thought group of four was the best size. Thus, teachers should consider this to evoke more cooperation and interaction among students in the group; larger groups may decrease each member's opportunity to actively participate. In short, the figures indicate that group work brought the benefits to most students which affect positively their learning outcomes.

Table 2: Students' views on using group work (percentage was combined)

\begin{tabular}{|l|c|c|}
\hline Working in group ... & Agree & Disagree \\
\hline received more useful/helpful feedback & $90 \%$ & $10 \%$ \\
\hline made you more confident & $100 \%$ & $0 \%$ \\
\hline helped you do tasks faster and better & $87 \%$ & $13 \%$ \\
\hline was a waste of time & $10 \%$ & $90 \%$ \\
\hline worked best when group size was four & $87 \%$ & $13 \%$ \\
\hline
\end{tabular}

As seen from the below pie chart, which demonstrates the students' attitudes to group work, a large proportion of the students liked working in group. Particularly, over half of students (57\%) expressed the strong agreement; $33 \%$ of them also opted for agreement response. The number of students found that group work was not interesting just occupied $10 \%$. That is to say that most students had a positive attitude to group work in the classroom.

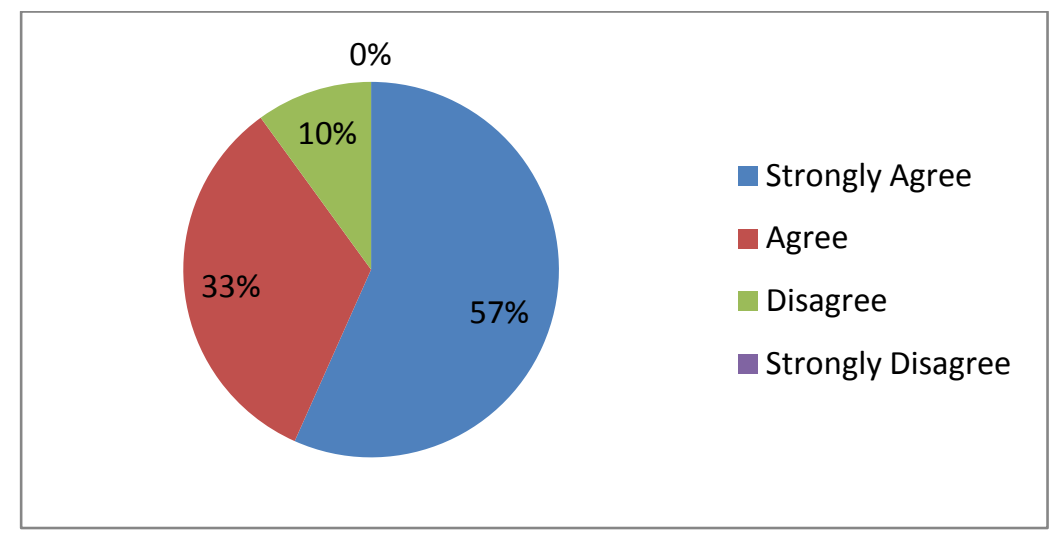

Pie chart 2: Students' attitudes toward group work

\subsection{The results from class observation}

On the first observation, the class continued unit 2 "Getting to know together" and the lesson was observed focusing on reading and speaking. Group work activities were used in this lesson including jigsaw and interview. After warmup activity, the students were divided into jigsaw group of five to read the newspaper article "Blind Date" which divided into five segments. Next activity, the students in group of four interviewed their peers to find out their opinions about blind dates with the suggested questions in the task. After each activity, the students were asked to make reports. From the observation sheet, it shows that the students in groups cooperated quite well; they discussed, and 
exchanged ideas or asked information to complete the tasks. Therefore, time for the students to speak English, communicate and interact with each other was quite much. However, there were not many students volunteer to report their answers. Some students answered correctly and fluently. The learning atmosphere in the class was relaxed and friendly.

In the next observation, the class continued unit 4 "The marketplace", and the lesson focused on vocabulary "shopping" and everyday English "prices". Two group work activities were guessing game and role-play used respectively in this lesson. The class was divided into groups of five for playing games and groups of three for role-play. As observed, the students actively participated in game, they well collaborated in the competition. The class atmosphere was noisy and lively. It seems that they had a lot of fun. Moreover, more students raised their hands to present the conversations that they took roles as sellers and customers. They made the conversations more fluently and played roles quite naturally. It proves that the students practiced a lot with their peers. However, using Vietnamese of some students was also noted by observer.

In a word, the data from class observation displays that the students had much time (about $70 \%$ ). to communicate and discuss in groups, while the teacher only gave instructions and monitored the groups and offered help. The class atmosphere was relaxed and lively, so most of the students actively participated in the activities. As a result, the students gained more opportunities for language practice in meaningful context through group work activities. In comparison with the first observation, it seems that the student demonstrated some improvements in their English speaking and confidence through the way they reported answers and made presentations in the classroom.

\subsection{The results from interview}

\subsubsection{The benefits of group work}

The data from the interviews suggests that group work in the classroom brought many advantages for students. Firstly, the students expressed that group work helped them to enhance their speaking ability because they had more opportunities to practice speaking English through working together. They recognized group work as an opportunity to express their opinions. Also, they were satisfied with face-to-face interaction and exchanging ideas in group context. As two students remarked:

I often watch English conversations on YouTube and I want to practice what I've learned, but I can't do it alone. When working together in group I could practice English speaking, I could use English in my way to exchange ideas or ask something from my peers in group. So I think group work is a good method to improve my English speaking. [S1]

After discussing and practicing with others in group, I fluently answered questions in English in front of the class. [S4]

Secondly, four students mentioned useful feedback like pronunciation errors, sentence structures in speaking that they received through peer participation in 
groups. They also learned new words and even recalled many words. One student stated:

I pronounced incorrectly some words during giving my ideas. One group member helped me correct them. It was useful for me. [S2]

Finally, the students revealed that group work created a positive climate in the classroom. So they were involved in lessons more often. They felt that group work helped reduce anxiety arising from whole-class working and made them more self-confident to give their opinions without fear of losing face if making mistakes. As one student noted:

Perhaps I'm not willing to the whole class. That's a quite big problem for me. I enjoy sharing my ideas and views in small group. [S5]

\subsubsection{Students' attitudes toward group work}

All five students expressed very positive feelings about using group work in the classroom. "I like it" was a common response in the interviews. However, they enjoyed group work for various reasons. Some of their answers were:

My peers assisted me very much. I had a lot of practice with my peers and got useful feedback and helpful suggestions. So I could perform better. [S1]

I enjoyed the way you allowed us to work in group. I liked learning with my peers. Although it sometimes went off on a tangent, I liked the 'relaxed' learning environment. [S3]

The students also gave the comments on group work activities. Generally, they agreed with the activities applied in the classroom because these activities helped them increase their confidence, improve speaking skills and created an active climate that motivated them; they felt more interested in the lessons. However, they revealed that they enjoyed role-playing and game best. They liked being exposed to real-life situations and competition. One student said:

I love role-play. I had a lot of fun and English practice with my peers. It was very interesting to undertake roles. [S2]

\subsubsection{The obstacles to working in group}

When being asked about what hinder them in participating in group work, the students reported their obstacles such as unclear instructions of activity, using native language and group member's contribution. One student said: "sometimes I was not clear about what I had to do". More responses from them as following:

Sometimes I felt unhappy because some group members were irresponsible. They didn't provide any help. [S4] 
One peer in my group didn't use English to discuss. She often used Vietnamese while the others tried to express themselves in English. [S1]

The students also gave the comments on group size, most of them thought that four people in a group would work more effectively. One of the students stated:

I liked working in group of four. It made every member become responsible and actively cooperate with each other. [S5]

\section{Discussion}

This research aims to evaluate the impact of using group work on students' speaking fluency and examine students' attitudes to the application of group work in classroom. The key results from class observation, questionnaire and interview indicate that using group work in the classroom brought many benefits in improving students' speaking fluency. This result is in line with those of previous researches such as Chen (2004); Brown (2001); Burdett \& Hastie (2009); Jiang (2009) and William (2011) which had claimed development of students' speaking ability with group work. First of all, group work gives the students more chances to practice new language; they can exchange ideas, practice new structures and have multiple interactions through group work. This finding is supported by Brown (2001) who has emphasized group work not only increase students' quantity of language practice opportunities, but also improve the quality of their talk. Moreover, group work creates a collaborative learning setting where the students can discuss together, clarify their own opinions and evaluate ideas to complete the assigned tasks and thus they can receive useful feedback for their speaking like pronunciation errors or sentence structures or learning new words from their peers. This result confirms previous literature that group work provides a meaningful context for peer-to-peer studying in which students may get support and encouragement through peer participation (Burdett \& Hastie, 2009). The other benefit group work brings is a positive learning climate in the classroom that makes the students feel safe and comfortable to speak English and feel more confident to express their opinions. This finding reflects the study outcome of Jiang (2009) who has proved that small group work creates a non-threatening and relaxed atmosphere for optional studying in the classroom. Besides, group work activities enable the students to use English in real-life situations. However, the findings show that using Vietnamese of some group members and teacher's unclear instruction of activity affect the effectiveness of group work.

As for the students' attitude to the application of group work in the classroom, the findings from questionnaire and interview illustrate that most students had positive attitudes to group work. This result contradicts with the finding of Wong (2004) that revealed students prefer working individually, but be consistent with the finding of Tiong and Yong (2004) that showed students enjoy doing group work in an informal setting. According to the research results, the students indicated that groups of four worked best, so this group size should be the maximum in the classroom. 
Obviously, using group work has brought the advantages for students in English class. However, to employ group work in classroom successfully and to maximize its effectiveness, teachers need careful preparation and planning before classes, proactive vitality during classes, and reflection afterward. The design and implementation of effective group work also demands practice and experience. Through this research with the roles as a teacher researcher, some suggestions are given from the experiences as follows:

\subsection{Suggestions}

Selecting appropriate group work activities is the first step in promoting successful group work, so teacher should select carefully group activities that relate closely to lesson contents and then design them to suit students' level. Teacher should also give very clear instructions about the activity, even modeling if possible; and time allotted to complete it. Then, teacher can ask several students to see if they have understood what they have to do in groups.

There are some ways that teachers need to consider to group students such as random, student-selected and teacher-selected grouping. However, once teacher knows students fairly well, teacher-selected grouping can be more effective. In such a group, better students can assist their weaker peers. Group size depends on the activity, but group of four students tend to work best. Therefore, teacher should consider maximizing this group size to increase participation and cooperation of each group member. To deal with overusing Vietnamese, at the beginning of the activity teacher should emphasize that students have to use English in group work. Moreover, teacher may set rules agreed by the class. Then, teacher goes around the class to remind students and give them language assistance.

\subsection{Limitation}

The chosen methods were suitable for the study which enabled the researcher to approach closely the subjects, to have insights into the research issues and context, and to collect the valuable data in order to address the research questions. Nonetheless, within the scope of this research, limitations are unavoidable. Firstly, the sample size was relatively small; the participants were freshmen who were adjusting the new studying habits, so the findings might not be stable. Accordingly, the results might not represent all non-majored English students of the university or other universities. Thus, further studies should be done to explore the effects of using group work with sophomores or juniors to see if they provide the same results. Secondly, class observation was made by only one teacher; as a result, the findings might be quite subjective. Moreover, the research duration was short, the validity and reliability of the findings were possibly influenced. Finally, some meaningful issues might not be investigated during implementing this research and the given suggestions may be incomplete and subjective. 


\section{Conclusion}

The research has shown that the application of group work brings the benefits in improving the students' speaking fluency. Group work provides more opportunities for the students to use English which allows a greater quantity and richer variety of language practice; working together creates a collaborative learning context in which the students can receive useful feedback from peers to better their speaking; and group work also brings a positive classroom atmosphere for the students to interact and use English freely that build up their confidence in speaking. As a result, the students have favorable attitudes to the use of group work activities in the classroom. Basically, these results have given the answers to the two research questions and concurrently contribute to the researcher's professional development in changing the teaching method to enhance the teaching performance and student's speaking ability. The study results are also beneficial to teacher colleagues at Dong Nai Technology University. Clearly, other teachers who want to improve their students' speaking skills should consider employing group work activities in classrooms.

\section{References}

Aldosary, A., \& Storch, N. (2010). Learner's use of first language (Arobic) in pair work in an EFL class. Language Teaching Research, 14 (4), 355-75. doi: 10.1177/1362168810375362

Beebe, S. A., \& Masterson, J. T. (2003). Communicating in small groups: Principles and practices. Boston: Allyn and Bacon.

Brown, D. (2001). Teaching by principles: An interactive approach to language pedagogy. New Work: Addison Wesley Longman.

Brumfit, C. (1984). Communicative methodology in language teaching. Cambridge: Cambridge University Press.

Burdett, J. \& Hastie, B. (2009). Predicting satisfaction with group work assignment. Journal of University Teaching and Learning Practice, 6 (1), 61-71.

Burke, A. (2011). Group work: How to use groups effectively. The Journal of Effective Teaching, 11 (2), 87-95.

Chaiyasuk, I., Setjun, P. \& Praphan, P. (2013). Improving sixth grade students' speaking skill through information gap with different task types and complexity. Humanities and Social Sciences, 7 (3), 43-45.

Chen, I. (2004). Utilizing group work effectively in the English language classroom. TESL Reporter, 37 (1), 1-7.

Chuku, C., Demewoz, N., Negash, N. \& Shamim, F. (2007) Maximizing learning in large classes. London: British Council.

Dahlberg, L. \& McCaig, C. (ed.). (2010). Practical research and evaluation: a start-to-finish guide for practitioners. London: Sage. doi: 10.4135/9781446268346

Davis, B. G. (1993). Tools for teaching. California: Jossey-Bass.

Doff, A. (1991). Teach English: a training course for teachers. New York: Cambridge University Press.

Dornyei, Z. (2003). Questionnaires in second language research: construction, administration, and processing, NJ: Lawrence Erlbaum Associates, Mahwah. 
Dumas, A. (2002). Cooperative learning - response to diversity. California Department of Education. Retrieved from http://www.cde.ca.gov/iasa/cooplrng2.html.

Fang, X. (2005). Sustaining CLT through group work in the Chinese EFL classroom. CELEA Journal, 28 (2), 39-43.

Felder, R. M. \& Brent, R. (2001). Effective strategies for cooperative learning. Journal of Cooperation \& Collaboration in College Teaching. 10 (2), 69-75.

Harmer, J. (2003). The practice of English language teaching. Oxford: Longman.

Hinchey, P. H. (2008). Action research primer. New York: Peter Lang.

Huie, K. \& Yahya, N. (2002). Researching English language learners through cooperative learning. The Internet TESL Journal, 8 (3). Retrieved from http://iteslj.org/Lessons/Yahya-Cooperative.html.

Jiang, J. (2009). Applying group work to improve college students' oral English. International Education Studies, 2 (3), 136-139. doi: 10.5539/ies.v2n3p136

Kelle, U. (2006). Combining qualitative and quantitative methods in research practice: purposes and advantages. Qualitative Research in Psychology, 3 (4),293-311.

Le, T. S. (2011). Teaching English in Vietnam: improving the provision in the private sector. (Ph.D. thesis). Victoria University, Melbourne.

McDonough, K. (2004). Learner-learner interaction during pair and small group work activities in a Thai EFL context. System, 32 (2)., 207-224. doi:10.1016/j.system.2004.01.003

Meng, F. (2009). Encourage learners in the large class to speak English in group work.

English Language Teaching, 2 (3), 219-224. doi: 10.1016/j.system.2004.01.003

Richard, J. C. (2001). Approach to evaluation. In Curriculum development in language teaching (pp. 286-309). Cambridge: CUP

Robinson, R. \& Savenye, W. C. (2005). Using qualitative research methods in higher education. Journal of Computering in Higher Education, 16 (2), 65-95. doi:10.1007/bf02961475

Salas, M. R. (2005). Grouping techniques in an EFL classroom. Revista Electrónica Actualidades Investigativas en Educación, 5 (7), 1-14. doi: 0.15517/aie.v5i3.9167

Stahl, R. J. (1994). The essential elements of cooperative learning in the classroom. ERIC Digest database, ERIC Clearinghouse for Social Studies/Social Science Education, doi: ED370881.

Thanomwattana, P. (2008). A Comparison of Communicative English Learning Achievement of Mathayomsuksa II Students by the Information Gap Principle and Teacher's Manual (Ph.D's thesis). Khonkaen University, Khonkaen.

William, S. (2001). Engaging and informing students through group work. Psychology Teaching Review, 17 (1), 24-34. 


\section{CONSENT FORM FOR PARTICIPANTS INVOLVED IN RESEARCH INFORMATION TO PARTICIPANTS:}

I would like to invite you to be a part of a study called "Using group work effectively to improve speaking fluency for first year non-majored English students at Dong Nai Technology University". The research aims to investigate the benefits of using group work in improving speaking fluency for first-year non-major English students at the university and identify students' attitudes toward the application of group work in the classroom.

\section{CERTIFICATION BY SUBJECT}

I, (name)

of (suburb)

certify that I am at least 18 years old and that I am voluntarily giving the consent to participate in the study: "Using group work effectively to improve speaking fluency for first year non-majored English students at Dong Nai Technology University"

Researcher and Primary Investigator: Phan Thi Lam

I certify that the objectives of the study, together with any risks and safeguards associated with the procedures listed hereunder to be carried out in the research, have been fully explained to me by Phan Thi Lam

and that I freely consent to participation involving the below mentioned procedures:

1. Completing a questionnaire (it takes about 15 minutes)

2. Being interviewed by the researcher (It takes about 20 minutes. Notes will be written during the interview. An audio tape of the interview will be made)

I certify that I have had the opportunity to have any questions answered and that I understand that I can withdraw from this study at any time and that this withdrawal will not jeopardise me in any way.

I have been informed that the information I provide will be kept confidential.

Signed: Participant Researcher

Date:

Any queries about your participation in this project may be directed to the Researcher,

Phan Thi Lam, 0983685405 
APPENDIX 2

CLASS OBSERVATION FORM

Lesson taken by:

Class:

Lesson observed by: Date and time:

\begin{tabular}{|l|l|}
\hline Goal: \\
\hline Focus: \\
\hline \multicolumn{1}{|c|}{ What will I be looking for? } & Observations - What did I see/hear/find? \\
\hline 1.Classroom organization & \\
\hline Student engagement & \\
Classroom management & \\
\hline Explicit teaching & \\
\hline Classroom atmosphere & \\
\hline Student questioning & \\
\hline Feedback & \\
\hline
\end{tabular}




\section{STUDENTS' QUESTIONNAIRE}

My name is Phan Thi Lam, an English teacher of Department of foreign languages. At present, I am conducting a research on "Using group work effectively to improve speaking fluency for first year non-majored English students". Your responses of the questions below give the valuable contribution to the research.

Date:

Gender: $\square$ Male

Female

Please tick $(\checkmark)$ only one response for each question.

$($ Strongly agree $=S A$, agree $=A$, disagree $=\mathbf{D A}$, and strongly disagree $=S D$ )

\begin{tabular}{|c|c|c|c|c|c|}
\hline No & Question & SA & $\mathbf{A}$ & DA & SD \\
\hline 1 & $\begin{array}{l}\text { Group work was an easy method to communicate } \\
\text { with others. }\end{array}$ & & & & \\
\hline 2 & $\begin{array}{l}\text { Group work provided more chances for speaking } \\
\text { practice. }\end{array}$ & & & & \\
\hline 3 & $\begin{array}{l}\text { You received useful/helpful feedback from peers in } \\
\text { group. }\end{array}$ & & & & \\
\hline 4 & $\begin{array}{l}\text { You became more confident about yourself in group } \\
\text { work. }\end{array}$ & & & & \\
\hline 5 & Group work helped you do tasks faster and better. & & & & \\
\hline 6 & You enjoyed working in group in the classroom. & & & & \\
\hline 7 & Group work was a waste of time. & & & & \\
\hline 8 & Group work worked best when group size was four. & & & & \\
\hline
\end{tabular}




\section{INTERVIEW QUESTIONS}

1. What have you learned useful in working in groups?

2. Did you enjoy group work? Why or why not?

3. How could group work help you in speaking English?

4. What group work activities do you prefer your teacher to use in classroom? Why?

5. What were your obstacles to working in group?

\section{APPENDIX 5}

Table: Results of the Questionnaire Frequency and Percentage

(Strongly agree $=S A$, agree $=A$, disagree $=\mathbf{D A}$, and strongly disagree $=S D$ )

\begin{tabular}{|l|l|c|c|c|c|}
\hline No & \multicolumn{1}{|c|}{ Question } & SA & A & DA & SD \\
\hline 1 & $\begin{array}{l}\text { Group work was an easy method to } \\
\text { communicate with others. }\end{array}$ & $\begin{array}{c}7 \\
(23 \%)\end{array}$ & $\begin{array}{c}20 \\
(67 \%)\end{array}$ & $\begin{array}{c}3 \\
(10 \%)\end{array}$ & $\begin{array}{c}0 \\
(0 \%)\end{array}$ \\
\hline 2 & $\begin{array}{l}\text { Group work provided more chances for } \\
\text { speaking practice. }\end{array}$ & $\begin{array}{c}9 \\
(39 \%)\end{array}$ & $\begin{array}{c}12 \\
(52 \%)\end{array}$ & $\begin{array}{c}2 \\
(9 \%)\end{array}$ & $\begin{array}{c}0 \\
(0 \%)\end{array}$ \\
\hline 3 & $\begin{array}{l}\text { You received useful/helpful feedback from } \\
\text { peers in group. }\end{array}$ & $\begin{array}{c}8 \\
(27 \%)\end{array}$ & $\begin{array}{c}19 \\
(63 \%)\end{array}$ & $\begin{array}{c}2 \\
(7 \%)\end{array}$ & $\begin{array}{c}1 \\
(3 \%)\end{array}$ \\
\hline 4 & $\begin{array}{l}\text { You became more confident about yourself } \\
\text { in group work. }\end{array}$ & $\begin{array}{c}20 \\
(67 \%)\end{array}$ & $\begin{array}{c}10 \\
(33 \%)\end{array}$ & $\begin{array}{c}0 \\
(0 \%)\end{array}$ & $\begin{array}{c}0 \\
(0 \%)\end{array}$ \\
\hline 5 & $\begin{array}{l}\text { Group work helped you do tasks faster and } \\
\text { better. }\end{array}$ & 15 & 11 & 3 & 1 \\
$(50 \%)$ & $(37 \%)$ & $(10 \%)$ & $(3 \%)$ \\
\hline 6 & $\begin{array}{l}\text { You enjoyed working in group in the } \\
\text { classroom. }\end{array}$ & $\begin{array}{c}17 \\
(57 \%)\end{array}$ & $\begin{array}{c}10 \\
(33 \%)\end{array}$ & $\begin{array}{c}3 \\
(10 \%)\end{array}$ & $\begin{array}{c}0 \\
(0 \%)\end{array}$ \\
\hline 7 & Group work was a waste of time. & 0 & 3 & 12 & 15 \\
$(10 \%)$ & $(40 \%)$ & $(50 \%)$ \\
\hline 8 & $\begin{array}{l}\text { Group work worked best when group size } \\
\text { was four. }\end{array}$ & $\begin{array}{c}17 \\
(57 \%)\end{array}$ & $\begin{array}{c}(30 \%) \\
(10 \%)\end{array}$ & $\begin{array}{c}3 \\
(3 \%)\end{array}$ \\
\hline
\end{tabular}

